\title{
Optimization of Local Materials in the Water Purification System as an Effort to Reduce Iron Content in Water Sources "Sumber Lestari" in the Manduro Village, Jombang District
}

\author{
Elly Setyowati ${ }^{1}$, Indasah ${ }^{2}$ \\ ${ }^{1}$ Public Health Center of Kabuh, \\ Jombang \\ ${ }^{2}$ IIK STRADA Indonesia \\ Email: \\ ellsetyowati7@gmail.com
}

\begin{abstract}
Background: Groundwater is the main source of drinking water in many countries around the world. It is an essential source of water for domestic, industrial and agricultural activities. Iron sometimes referred to as "fly in the ointment" has been one of the most troublesome domestic water contaminants. Various quantities of iron are often present in water because of large amounts of iron present in the soil and because corrosive water will pick up iron from pipes clothing washed in water containing excessive iron may become stained with a brownish colour. The study aims to develop a cheap and easy technology to reduce the presence of excess iron in groundwater. Methods: The iron removal system is developed by slow sand filter and selecting coconut husk fibre as the substrate material of filter media. The filter media made from coconut husk fibre $15 \mathrm{~cm}$, plain sand 15 $\mathrm{cm}$, coconut husk fibre $20 \mathrm{~cm}$, plain sand $20 \mathrm{~cm}$, charcoal 15 $\mathrm{cm}$, grave $10 \mathrm{~cm}$ and mineral stones $15 \mathrm{~cm}$. The developed technique seemed to be very effective in reducing the iron concentration below $0.3 \mathrm{ppm}$ as required Permenkes RI No. 492/MENKES/PER/IV/2010. Result: The research result show that filter media could reduce iron content. The efficiency of the filter media in reduce of iron content is about $71-96 \%$. Conclusions: Media filter is effective for reduce iron content in groundwater up to $96 \%$ and has fulfilled Permenkes RI No. 492/MENKES/PER/IV/2010.
\end{abstract}

Keywords: Ground water, iron, water filter, coconut husk fiber

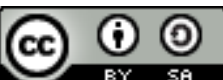

This is an open-acces article distributed under the terms of the Creative Commons Attribution-ShareAlike 4.0 International License.

\section{INTRODUCTION}

Groundwater is the main source of drinking water in many countries around the world. It is an essential source of water for domestic, industrial and agricultural activities. Over the last few decades and due to rapid industrialization and agricultural activities, numerous cases of groundwater po lution havebeen reported. These pollutants affect the quality of groundwater and make it unsuitable for human and irrigation uses. One of the major problems related to groundwater is its reddish and blackish properties due to the high content of iron $(\mathrm{Fe})$ and manganese.

Although iron is an essential mineral for human, its presence in ground water above a threshold level make the water unusable mainly for aesthetic considerations such as discoloration, metallic taste, odor, turbidity and staining of laundry. Iron is mainly present in water either the soluble ferrous iron or the insoluble ferric iron. Water containing ferrous iron is clear and colourless due to its 
soluble nature. On exposure to air the ferrous iron is converted to ferric iron and turns water reddish brown appearance. Moreover, iron oxides, which are formed in reservoirs upon aerial oxidation of dissolved iron promotes growth of microorganism.

It is difficult to removal iron complexed with other organic and inorganic compounds. It has high solubility in aqueous substances. Common methods used for iron removal includes chemical precipitation, coagulation-flocculation, flotation, ultrafiltration, nanofiltration, reverse osmosis, electrochemical treatment techniques like electro dialysis, membrane electrolysis, electrochemical precipitation, electroextraction. (Kulkarni,2016). However, Adsorption is by far most adaptable and effective method to reduce any contaminants like heavy metal, especially, if adhered with suitable regeneration steps. Adsorption is a process in which a single or a group of ions/compounds get accumulated on the surface of another solid or liquid. Its process involves a mass transfer operation through which constituents in the liquid phase are transferred to the solid phase (Metcalf \& Eddy, 2003; Kumar et.al, 2004). The substance on which the adsorption occurs is known as adsorbent and the substance which gets adsorbed or accumulated is called adsorbate. Many adsorbents have been tested for the adsorption of iron. Previous research has reviewed the potential use of adsorbents for the removal of iron from aqueous solutions such as clinoptilolite (Oztaz et al., 2008), eggshell (Yeddou et al., 2007) and activated carbon (Okoniewska et al., 2007)

A commonly practiced $\mathrm{Mn}$ and $\mathrm{Fe}$ treatment approach is to chemically oxidize dissolved $\mathrm{Mn}$ (II) to particulate $\mathrm{Mn}$ (IV) or dissolved $\mathrm{Fe}(\mathrm{II})$ to particulate $\mathrm{Fe}(\mathrm{III})$, followed by physical separation of the insoluble precipitates from water using clarification and filtration processes. However, most of those are not applicable for wastewater treatment due to their low removal efficiencies when the heavy metal concentrations are lower than $100 \mathrm{mg} \mathrm{L}^{-1}$. In contrast, activated carbon may effectively remove heavy metals from wastewater even at low concentrations . Despite this advantage, the use of the activated carbon adsorption process for the removal of heavy metals has been limited as it requires high maintenance and operational costs. In recent years, biochars, which can be produced at low cost, have attracted great attention as an alternative to activated carbon. Biochar is an ecofriendly adsorbent produced using by-products of the agricultural industries and wastes from various crops, and is effective for removing heavy metals from wastewater. Over the wide range of crops, bananas cultivated in more than 130 countries are regarded to be one of the most widely grown tropical fruits in the world. Raw biochars have showed feasibility for adsorbent material to remove contaminants including heavy metals and organic pollutants. However, the sorption capacities can be enhanced by treatment with acids, nanocomposites, and activation agents. For example, Chu et al. showed that phosphoric acid treatment improved the porosity of biochars from pine sawdust, cellulose, and lignin. The modified biochars provided better sorption of carbamazepine and bisphenol A. The sorption for 15 different pesticides by biochars from rice straw and corn stover was also increased by phosphoric acid treatment due to increased functional groups and aromatization of the biochars. Considering the effects of phosphoric acid treatment on porosity and the modification of functional groups of biochars, the treatment method can be applied to improve removal efficiencies of heavy metals by biochars from other sources. In addition, phosphoric acid has advantages in low pyrolysis temperature, low cost, and low corrosivity to the equipment. Nevertheless, to the best of our knowledge, phosphoric acid pre-treatment has not been used to enhance the physicochemical properties of biochars from banana peels in association with the adsorption of heavy metals. The main purpose of this study was to evaluate the effects of phosphate pre-treatment on the adsorption of heavy metals (i.e., $\mathrm{Mn}$ and $\mathrm{Fe}$ ) using biochars prepared from banana peels. First, the physicochemical characteristics of pristine and phosphoric acid pre-treated biochars derived from banana peels were rigorously characterized. Then, various adsorption experiments were conducted to investigate optimum adsorbent dosages, adsorption kinetics, adsorption isotherms, and effects of temperature and ionic strengths on adsorption. The improved adsorption efficiencies by phosphoric acid treatment were analyzed based on the physicochemical characteristics of the biochar, and the adsorption mechanisms of $\mathrm{Mn}$ and Fe were discussed. This study improves our understanding of the effect of phosphoric acid treatment on modification of the surface structure and functional groups of biochars for heavy metal removal. (Kim et al, 2020)

In recent years, the purification of natural water, improvement of water preparation technologies and development of new effective resource-saving methods becomes more and more actual. European Union devoted to surface and ground water protection. The directive attributes a great role to the protection of aquatic and water related ecosystems. Water supply of most small and medium-sized settlements carries out by underground sources. This is almost the entire population in Ukraine of northern, western, northeastern and other regions. In most cases, underground water contains high amount of iron (usually to $3 \mathrm{mg} / \mathrm{dm}^{-3}$ ), hydrogen sulphide, free carbon dioxide. Excessive amounts of iron in the water not only causes formation of unpleasant smells, turbidity, 
colour of water, overgrown of water pipes but also adversely affects human health. Therefore, before using water for drinking purposes is necessary to remove this component. In recent years, the purification of natural water, improvement of water preparation technologies and development of new effective resource-saving methods becomes more and more actual. Iron removal method chosen depending on the chemical water composition, the degree of iron-removing, water treatment station productivity, etc., based on the technological tests. Most often nonchemical method is used for ironremoving of water because it is easier and cheaper. The effectiveness of iron removal of water in granular filters depends on many factors that can be grouped into the following major groups: physicochemical indicators of quality of underground water, characteristics of the filters downloading, method of water preparation before its filtration, technological parameters of filters work. For iron removal of underground water are used various types of filtering. The construction of the filtering equipment and auxiliary equipment usually depends on the type of downloads. The use of "heavy" downloads (sand, gravel, zeolite, etc.) require additional equipment for organization of washing. However, coarsegrained downloading, such as granite gravel, requires very high airflow and washing water. Therefore, the operation of such filters is complicated. Such treatment can be provided by slow sand filtration. This process has been recognized as an appropriate technology for drinking water treatment in rural areas, and is recognized as asuitable filtration technology for removing water borne pathogens, organics and reducing turbidity.

Slow sand filters can be constructed from local materials, mainly from properly graded sand/gravel and standard piping and can operate without the use of specialized equipment. Also, slow sand filters operate under gravity flow conditions and energy and its on-going energy demand is minimal. (Yassir, 2018)

A method for removal of iron from water by using the modified coconut shell charcoal has been systematically investigated. The iron removal results from the adsorption of oxygen followed by the oxidation of $\mathrm{Fe}^{2+}$, catalyzed by the adsorbent carbon surface. The $\mathrm{Fe}^{3+}$ precipitates on the solid, forming a hydrated iron oxide coated carbon that is also able to absorb iron. The present modified coconut shell charcoal has been found to be very effective and remove iron to below $0.3 \mathrm{ppm}$ in water without increasing the $\mathrm{pH}$ above the acceptable limit.

Usually processed coconut fibre used in the agricultural sector, especially for characteristics other than fibre absorbs water used in industry. Coconut husk fibre was function as the main filter to screen out large solids such as algae. This material can withstand suspended solids due to the physical characteristics of the fibre solids capable of withstanding large. This material is as a substitute for the existing filter material on the market. Pollutant will be absorbed during the treatment process (Emm,2019).

This study was carried out to evaluate the efficiency of slow sand filtration with coconut fibre absorbent in removing for reduce iron content from groundwater in the Manduro village in Kabuh region Jombang city and try to facilitate the understanding of the mechanism of this filtration process.

\section{MATERIALS AND METHODS}

Groundwater sampling Groundwater samples were collected from 25 different locations in Manduro village, Kabuh, Jombang city. Manduro Village is located 50 meters above sea level and located in the limestone hills known by as Mount Celeng.

\section{Filter Media Preparation}

The iron removal system is developed by slow sand filter and selecting coconut husk fibre as the substrate material of filter media. The dimension of filter media were height $135 \mathrm{~cm}$, width 20 $\mathrm{cm}$ and length $20 \mathrm{~cm}$. Then given a hole that is $5 \mathrm{~cm}$ from the bottom of the filtration tube with the size half an inch for the outlet.

The filter media made from coconut husk fibre $15 \mathrm{~cm}$, plain sand $15 \mathrm{~cm}$, coconut husk fibre $20 \mathrm{~cm}$, plain sand $20 \mathrm{~cm}$, charcoal $15 \mathrm{~cm}$, grave $10 \mathrm{~cm}$ and mineral stones $15 \mathrm{~cm}$.

Coconut husk fibre was collected from a nearby coconut mill in Kabuh, Jombang city. To remove all the dirt particles, impurities and bisphenol, coconut husk fibre was washed several times with tap water followed by distilled water. The coconut husk was boiled in boiling water $100{ }^{\circ} \mathrm{C}$.

\section{Picture 1. Desain of filter media}




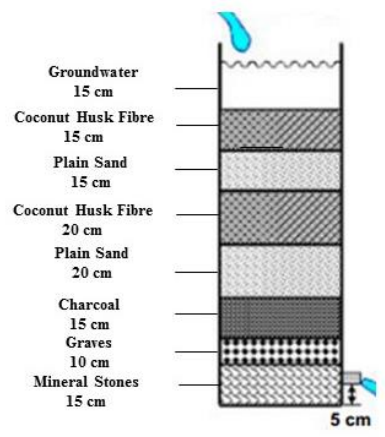

\section{RESULTS}

The filter media that have been made in this research were shown in Figure 2

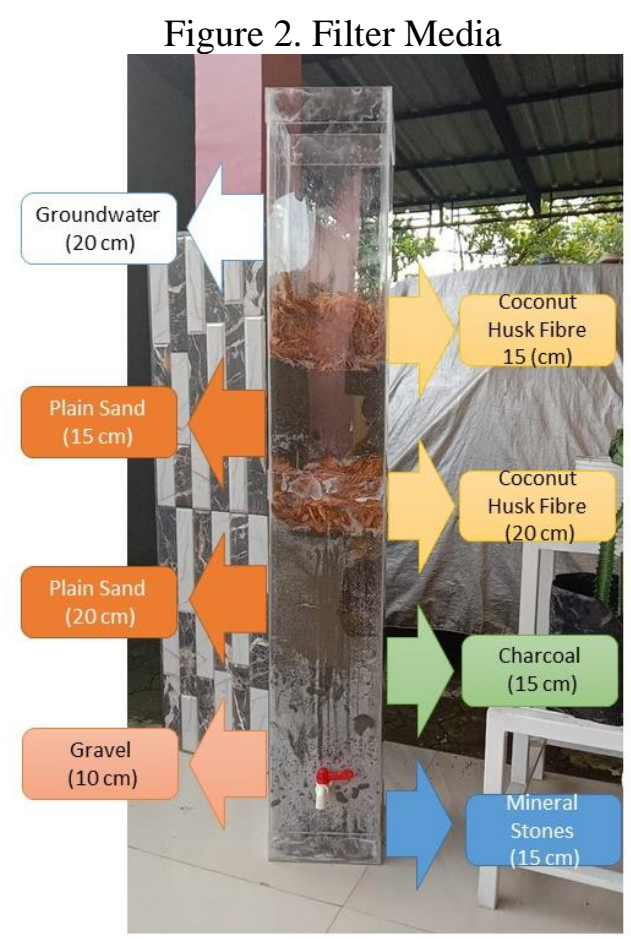

Groundwater which used in this research were collected from Kabuh District with. Samples were taken randomly at 5 hamlet. In this chapter describes the data and analysis related to the results of measurements of groundfall before and after passing through a water filter production using coconut husk fiber, charcoal (activated carbon), sand, gravel and mineral stones for groundwater harvesting from the tests was conducted. Data the parameters tests of iron using a spectrophotometer is shown in table and graphical forms. This data is important for the data and analysis concerning the design of this model. The groundwater samples was taken which is 25 of groundwater before filtered and 25 samples of groundwater after filtered.

Table 1. Effectivity of filter media

\begin{tabular}{cccccccccccccccc}
\hline \multirow{2}{*}{ Area } & \multicolumn{4}{c}{ Before Filtered } & \multicolumn{1}{c}{ After Filtered } & \multicolumn{5}{c}{ Effectivity (\%) } \\
& I & II & III & IV & V & I & II & III & IV & V & I & II & III & IV & V \\
\hline 1 & 9,2 & 8,6 & 9,2 & 9,5 & 6,1 & 0,9 & 1 & 0,9 & 0,68 & 0,4 & 90 & 88 & 90 & 93 & 93 \\
2 & 10 & 8,8 & 6 & 8,6 & 6 & 0,85 & 0,92 & 0,55 & 0,5 & 0,5 & 92 & 90 & 91 & 94 & 92 \\
3 & 6 & 7,1 & 7,2 & 6,2 & 8,7 & 0,55 & 0,98 & 0,6 & 0,46 & 0,5 & 91 & 86 & 92 & 93 & 94 \\
4 & 2,25 & 10 & 3,5 & 6,2 & 4,2 & 0,65 & 0,98 & 0,1 & 0,25 & 0,3 & 71 & 90 & 97 & 96 & 93 \\
5 & 1,7 & 10 & 5,6 & 5,8 & 2,25 & 0,25 & 0,98 & 0,25 & 0,35 & 0,5 & 85 & 90 & 96 & 94 & 78 \\
\hline
\end{tabular}




\section{DISCUSSION}

Based on the measurement results, the iron content in the water consumed by people in Manduro village is around $1.7-10 \mathrm{~g}$. $\mathrm{L}^{-1}$. The difference in Fe content at each point is caused by the distance from the water source to the residents' houses. The sample the most fastest from source water have the higher the Iron content, because the Fe deposition in the pipelines will be more followed by the flow of water.Iron is one type of mineral needed by the body of living things. Iron is an element that is important and useful for body metabolism. Small amounts of iron are needed by the body for the formation of red blood cells. However, if the iron content exceeds the clean water requirements required by the Indonesian Ministry of Health, it has been stipulated through Permenkes RI No. 492 / MENKES / PER / IV / 2010 amounting to $0.3 \mathrm{mg} / \mathrm{L}$ will have a bad impact on the environment and society. According to Soemirat (2014) in drinking water, Iron causes taste, yellow color, deposition on pipe walls, growth of iron bacteria, turbidity, even in large doses can damage the intestinal wall to death. This high concentration of Iron can be felt and can stain fabrics and kitchen utensils. Ferihidroxide can precipitate and is brownish yellow. It can stain porcelain and laundry utensils (Slamet, 2004). In addition, concentrations greater than $1 \mathrm{mg} / \mathrm{l}$ can cause the water to become reddish in color, have an unpleasant taste in drinks, can form deposits on metal pipes and laundry materials.

The source water used has the characteristic odor, is cloudy, and yellowish, this is due to the presence of iron $(\mathrm{Fe})$ in the source water. In surface water, Iron content is rarely found greater than $1 \mathrm{mg} / \mathrm{l}$, but in groundwater, Fe content can be much higher. Groundwater contains dissolved iron in the form of ferrous $\left(\mathrm{Fe}^{2+}\right)$. The source water is used by residents for daily activities such as washing, bathing, cooking and drinking. This research was conducted to determine the decrease in iron levels by filtration methods using a combination of slow sieve methods. The filtering process takes place by gravity, very slowly, and simultaneously on the entire surface of the media. The filtering process is a combination of physical processes (filtration, sedimentation and adsorption), biochemical processes and biological processes. The filtration process that occurs in slow sand filters occurs by separating water from the contaminants in the form of suspended particles and colloids, as well as bacteria, by passing water through a porous medium. In principle, this material can be any material, such as a granular layer of sand, crushed stone, anthrachite, glass, charcoal residue, etc. The media used in this study consisted of coconut husk, plain sand, charcoal, gravel and stones. The choice of material is because the material is easily found in large quantities, the cost is low, and the processing results provided are also very satisfying.

1. Plain Sand Fine sand and gravel are naturally occurring glacial deposits high in silica content and low insoluble calcium, magnesium and iron compounds are very useful in sedimentation removal. But here the media is used for iron removal from drinking water. Here for the experiment at ion plane sand passing through 425 micron and 600 Micron IS sieve were used.

2. Gravel is used in filter media or filters because it is a filter that separates the finest suspended solids and also separates solids or colloids from liquids, where the process can be used as a primary treatment (Sagala, 2014).

3. Charcoal also called activated carbon, is a form of carbon processed to have small, lowvolume pores that increase the surface area available for adsorption or chemical reactions. Activated is sometimes substituted with active. Due to its high degree of micro porosity, just one gram of activated carbon has a surface area in excess of 3,000 $\mathrm{m} 2(32,000$ sq.ft), as determined by gas adsorption. An activation level sufficient for useful application may be attained solely from high surface area; however, further chemical treatment often enhances adsorption properties.

4. Mineral stone are mined between 60 and 330 meters below sea level on an unpolluted koreon island. The mineral stone contains Germanium which promotes health and prevents cancer. Germanium also absorbs heavy metals, toxins, odour and impurities, the continuously releases more than 30 kinds of ionized minerals for 5 years, and gradually depleting in size. The highly porous mineral stone aid in the oxygenation of water and in the adjustment of the $\mathrm{pH}$ of water mild alkaline (Emm, 2018).

5. Coconut husk fibre is one of the easily available biomass and is a byproduct of agriculture. The composition of coir in coconut is about $35 \%$ of the total weight of the coconut. Coconut husk fibre consists of firers (fibre) and cork (pitch) that connect one fibre to another. Coconut coir consists of $75 \%$ fibre and $25 \%$ cork. The potential of using coconut husk fibre as a biosorbent to remove heavy metals from waters is quite high because coconut husk fibre contains lignin (35\% - 45\%) and cellulose (23\% -43\%) (Carrijo, et al. 2002). Coconut coir 
fiber is very potential as a biosorbent because it contains cellulose, which in its molecular structure contains carboxyl groups and lignin which contains phenolic acids which take part in metal binding. Cellulose and lignin are biopolymers associated with the separation of heavy metals (Pino, et al. 2005).

Efectivity of media filter to reduce iron content is calculated using the formula:

$$
\text { eff }=\frac{F e \text { content }(\text { in })-F e \text { content }(\text { out })}{F e \text { content }(\text { in })} \times 100 \%
$$

the effectivity of the media filter in reduce of iron content is about $71-96 \%$.

\section{CONCLUSION}

The conclusion of this study were

1. Iron content of groundwater used in the study were 1.7 - $10 \mathrm{ppm}$, after filtering using filter media, iron content was $0.1-1 \mathrm{ppm}$.

2. Media filter is effective for reduce iron content in groundwater up to $96 \%$ and has fulfilled Permenkes RI No. 492/MENKES/PER/IV/2010

\section{ACKNOWLEDGEMENT}

Researchers are very grateful to resident and community leaders in the neighborhoodof Manduro Village, Kabuh Distric, Jombang Regency, East Java province who have voluueered to be involved in tesearch activities.

\section{CONFLICT OF INTEREST}

There were no conflicts of interest before, during and after this research was completed.

\section{REFERENCES}

Carrijo O, Liz R, Makishima N. 2002. Fiber of green coconut shell as an agricultural substrate. Hortic Bras 20(4). Pp 533-535

Emm Lil .2018. Water Filter Production Using Coconut Husk Fiber, Zeolite, Charcoal and, Membrane for Rainwater Harvesting. Downloaded at 15 January 2020 at https://www.researchgate.net/publication/326682453

Kim, Hyunjoon. Ko, Ryun-Ah. Lee Sungyun. Chon Kangmin. 2020. Removal Efficiencies of Manganese and Iron Using Pristine and Phosphoric Acid Pre-Treated Biochars Made from Banana Peels. Water . 12, 1173; doi:10.3390/w12041173. pp 1-13

Kumar U., and Bandyopadhyay M. 2006. Fixed Bed Column Study for Cd (II) Removal From Wastewater Using Treated Rice Husk. Journal of Hazardous Waste Materials B129. pp $253-259$

Okoniewska E., Lach J., Kacprzak M., and Neczaj E. 2007. The removal of manganese, iron and ammoniumnitrogen on impregnated activated carbon. Desalination 206. pp 251-258

Metcalf \& Eddy. 2003. Wastewater Engineering: Treatment and Reuse. Mc Graw-Hill Higher Education. New York, USA

Pino, G.H., Mesquita, L.M.S., Torem, M.L., Pinto, G.A.S.. 2005. Biosorption of Cadmium by Green Coconut Shell Powder, Separation Science And Technology. Volume 41, 2006 - Issue 14

Teknik Penyaringan Air.2012. viewed 18 January 2020 at http://nanosmartfilter.com/teknikpenyaring-air/

Permenkes RI No. 492/MENKES/PER/IV/2010. Retrieved from https://www.google.co.id/url?sa=t\&source=web\&rct=j\&url=https://www.mapurna.id/files/SK_Permenkes_492_2010.pdf\&ved=2ahUKEwixpOfi _qbuAhVugUsFHZnmCQ4QFjACegQIEBAB\&usg=AOvVaw3bBEGxWxqAgmhAa-us0wYn

Soemirat J. 2014. Kesehatan Lingkungan. Yogyakarta: Gadjah Mada University Press

Sagala, Hendri Trisno. 2014. Uji Penambahan Media Tanah pada Saringan Pasir Lambat Pipa (SPLP) terhadap Beberapa Parameter Kimia Air Hasil Penyaringan. Fakultas Pertanian Bengkulu

Sunil J. Kulkarni, Sunil J. 2016. A Review on Studies and Research on Iron Removal. International Journal of Science and Healthcare Research. Vol.1; Issue: 2, pp 49 - 52

Yassir, Barkouch. Chaimae, Zahar. Melloul, Ait Abdelaziz. Eddine, El Khadiri Mohy. Alain, Pineau .2018. New Approach to Understand the Removal Efficiency of Some Anions in Well Water 
by Slow Sand Filtration. Annual Research \& Review in Biology 23(1): Article no.ARRB.38905 ISSN: 2347-565X, NLM ID: 101632869. Pp 1-8

Yeddou, and A. Bensmaili. 2007. Equilibrium and kinetic modeling of iron adsorption by eggshells in a batch system: effect of temperature. Desalination 206. Pp. 127-134 